\title{
A Feasible Way of Degrading Malathion Pesticide under Laboratory Condition Using Phosphate Solubilizing Bacteria
}

\author{
Pratyasha Chakma ${ }^{1,2}$, Sumaiya Chowdhury ${ }^{1,2}$, Latiful Bari2 ${ }^{*}$, Sirajul Hoque ${ }^{1}$ \\ ${ }^{1}$ Department of Soil, Water and Environment University of Dhaka, Dhaka, Bangladesh \\ ${ }^{2}$ Food Analysis and Research Laboratory Centre for Advanced Research in Sciences University of Dhaka, Dhaka, Bangladesh \\ Email: *latiful@du.ac.bd, sirajulhoque@du.ac.bd
}

How to cite this paper: Chakma, P., Chowdhury, S., Bari, L., \& Hoque, S. (2019). A Feasible Way of Degrading Malathion Pesticide under Laboratory Condition Using Phosphate Solubilizing Bacteria. Journal of Geoscience and Environment Protection, 7, 1-12.

https://doi.org/10.4236/gep.2019.71001

Received: October 18, 2018

Accepted: January 15, 2019

Published: January 18, 2019

Copyright $\odot 2019$ by author(s) and Scientific Research Publishing Inc. This work is licensed under the Creative Commons Attribution International License (CC BY 4.0).

http://creativecommons.org/licenses/by/4.0/

\begin{abstract}
An experiment was carried out for identification and determination of malathion degrading phosphate solubilizing bacteria isolated from the agricultural fields. In this study, malathion degrading phosphate solubilizing bacteria were identified using NBRIP (National Botanical Research Institute's phosphate growth medium) media. A number of bacterial colonies were screened from agricultural fields. From primarily screened colonies 4 isolates were identified as phosphate solubilizing bacteria through qualitative and quantitative analysis. The isolated 4 bacterial colonies were inoculated in NBRIP broth media enriched with malathion pesticides to observe degradation of malathion pesticide under incubation study at three different temperatures $\left(25^{\circ} \mathrm{C}, 30^{\circ} \mathrm{C}\right.$ and $\left.37^{\circ} \mathrm{C}\right)$. However, all the four isolates showed capability in degrading malathion pesticide. The study clearly revealed that phosphate solubilizing bacteria can be used in bioremediation of environmental pollution caused by malathion pesticide.
\end{abstract}

\section{Keywords}

Malathion, NBRIP Media, Phosphate Solubilizing Bacteria (PSB), Bioremediation and Degradation

\section{Introduction}

Bangladesh is facing many challenges in agricultural sector in the coming years. In order to secure food demand for its vast population, more toxic chemicals are used that have reputations of speed and effectiveness to increase food production. The Government of Bangladesh also promotes the use of pesticides to increase output per acre of land. Overall, pesticide use in general is increasing. 
They provide unquestionable benefit for agricultural production, even though, as a consequence, low amounts of some residues may persist in the food supply, air, water and soil and could constitute a significant exposure pathway for humans (Ghorab \& Khalil, 2016). The growing use of pesticides in contemporary agriculture has direct or indirect impact on the composition of soil microorganisms. It is stated that usually more than $10^{9}$ microorganisms are present per gram of soil representing 4000 to 7000 different genomes and biomass of 300 to $3000 \mathrm{~kg}$ per ha (Ranjard \& Richaume, 2001) which directly or indirectly are affected by many conditions of these insecticides used. If pesticides can be degraded as soon as they are applied, then their desired function will not be served.

Pesticide biodegradation by microorganisms has been documented in a wide range of habitats, including soils, ground water and sewage sludges etc. Insecticides and their degradation products generally get accumulated in the top soil and influence not only the population of various groups of soil microbes but also their biochemical activities like nitrification, ammonification, decomposition of organic matter and nitrogen fixation (Agnihotri et al., 1981). Recently, use of microbes for effective detoxifying, degrading and removal of toxic compounds from contaminated soil and water has emerged as an efficient technique to clean up polluted environments (Strong \& Burgess, 2008).

Malathion [diethyl 2-\{(dimethoxyphosphorothioyl) sulfanyl $\}$ butanedioate] is one of the common pesticides used in pest control programs in Bangladesh. In this study malathion was degraded by using Phosphate solubilizing bacteria under laboratory condition. As it is reported that phosphate solubilizing bacteria are capable of mineralizing organic phosphorous compound, so it is expected that these bacteria will be able to degrade organophosphate malathion releasing soluble phosphorous.

So, the efficiency of the isolated microorganisms to metabolize malathion in order to develop safe, convenient and economically feasible methods for pesticide detoxification would be investigated under this study.

\section{Methods and Materials}

Soils were collected from the area of Sirajganj, Tangail and Madhupur (Figure 1). All samples were collected from agricultural fields, where the common agricultural crop is paddy rice (Oryza sativa); other minor crops were also present in some of the fields such as Lady's finger (Hibiscus esculentus), Amaranthus (Amaranth sp) or Indian spinach (Basellaceae sp).

\subsection{Description of the Sampling Sites}

Sirajganj: Soil sample was collected from agricultural field of Sirajganj. The GPS location of the sampling point where soil samples were collected was approximately $24^{\circ} 24^{\prime} 27.7164^{\prime \prime} \mathrm{N}$ and $89^{\circ} 38^{\prime} 7.1376^{\prime \prime E}$. Sirajganj falls under Precambrian platform and is characterized by sedimentary rocks above a Precambrian igneous and metamorphic basement. The area lies in the active delta region of 


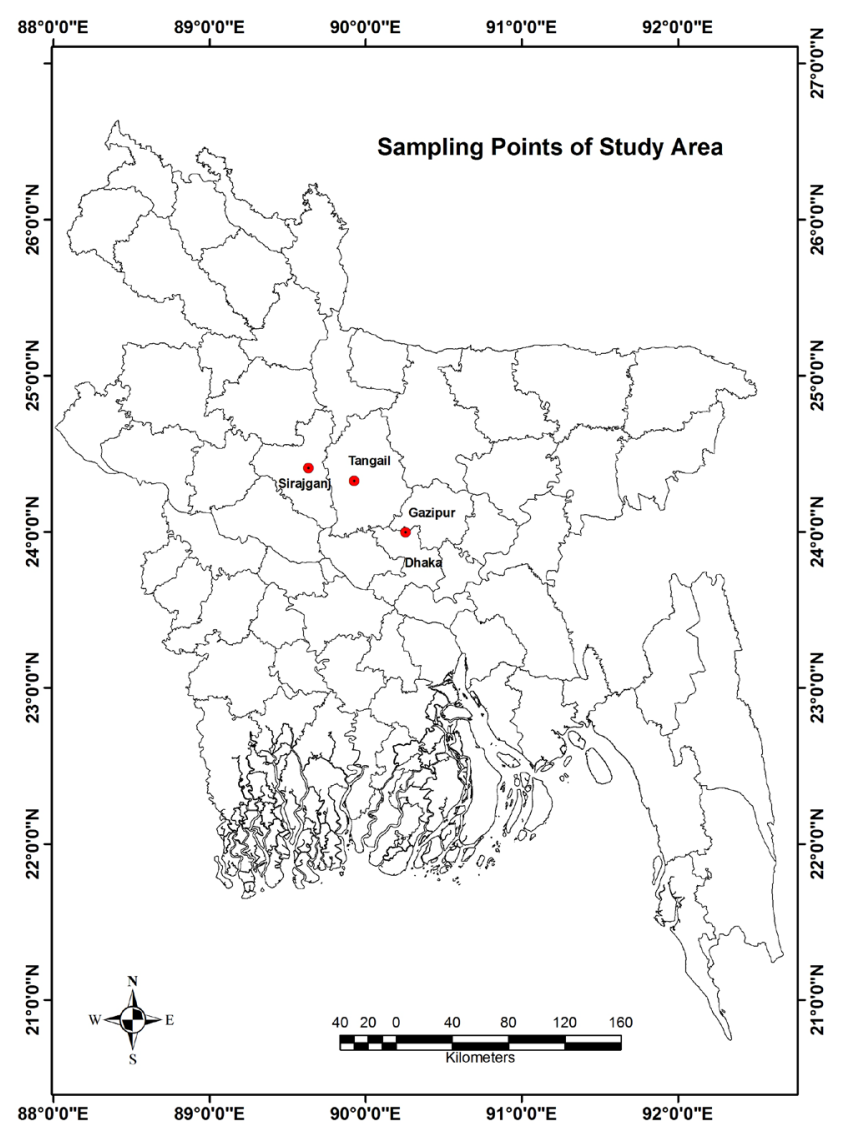

Figure 1. Location of the sampling site.

Brahmmaputra-Jamuna floodplain and general soil type is grey floodplain soils (Figure 2). The climate is characterized by high temperature, heavy rainfall, often excessive humidity and fairly marked seasonal variation.

Tangail: Soil sample was collected from agricultural field which is situated beside Joydevpur-Tangail-Jamalpur highway. The GPS location of the sampling point where soil samples were collected was approximately $24^{\circ} 19^{\prime} 35.1336^{\prime \prime} \mathrm{N}$ and $89^{\circ} 55^{\prime} 33.7656^{\prime \prime}$. The parent material of soil is Brahmaputra-Jamuna alluvium and general soil type is grey floodplain soils (Figure 2). The area is covered by the recent alluvial flood plain deposits which are underlain by the Pleistocene Madhupur Clay deposits. It has tropical climate with less rainfall in summer and winter.

Gazipur: The sample is collected from agricultural site which is situated in Zirani bazar, Madhupur, Gazipur district. The GPS location of the sampling point where soil samples were collected was approximately $23^{\circ} 59^{\prime} 45.5856^{\prime \prime} \mathrm{N}$ and $90^{\circ} 15^{\prime} 21.564^{\prime \prime} \mathrm{E}$. The area is categorized under red-brown general soil type (Figure 2). The Madhupur area is covered by Madhupur Clay Residuum of Pleistocene age, underlain by Plio-Pleistocene Dupitila Sandstone Formation and adjacent flood plains of the Jamuna and the old Brahmaputra river are characterized by the Holocene alluvium deposits. The climate of the Tract varies slightly from north to south, the northern reaches being much cooler in winter. 


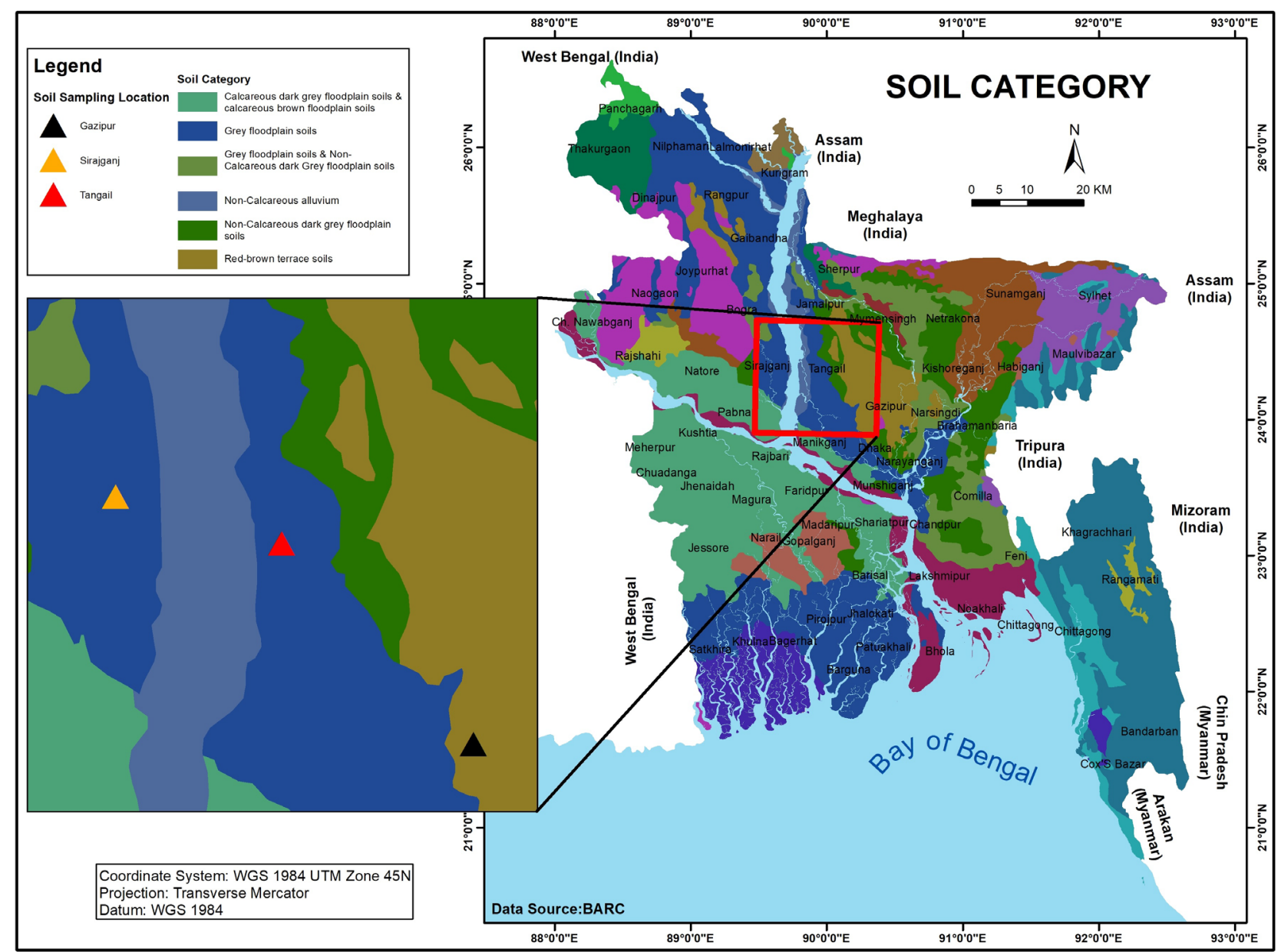

Figure 2. General soil type map.

\subsection{Malathion Pesticide}

Malathion (57\%) a commercial grade pesticide used mainly for pest control was collected from local pesticide shop from Dhaka, Bangladesh. The pesticide belongs to organophosphate class of pesticides.

\subsection{Characterization and Identification of Phosphate Solubilizing Bacteria}

The samples were collected from $8-10 \mathrm{~cm}$ depth using a sterile spatula and transferred to autoclaved Ziplock bag stored under room temperature. Figure 3 illustrates the flowchart of soil collection and processing for identification of phosphate solubilizing bacteria. Soil samples were air dried and crushed before sieving. $0.5 \mathrm{~mm}$ sieve was used for microbiological analysis and $2 \mathrm{~mm}$ sieve was used for determination of chemical properties of soil. To isolate bacteria, serial dilution plate technique was carried out (Greenberg et al. 1980). When colonies appeared, they were counted and recorded and were purified through repeated plating (by streak plate method) (Cappuccino \& Natalie, 2012). These isolated colonies were identified by some morphological and biochemical tests such as shape, arrangement, colonies, form, margin, elevation, colour, Gram reaction, 


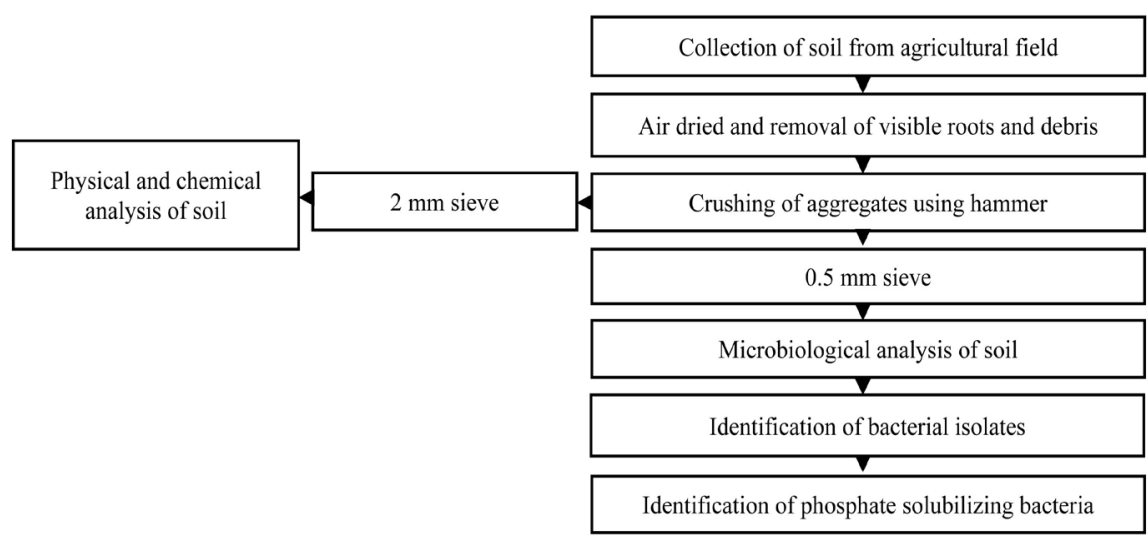

Figure 3. A Flowchart of soil collection and processing for identification of phosphate solubilizing bacteria.

Oxidase test, Catalase test, Oxygen requirement, Gelatin liquefaction, indole production test, methyl red and Voges-Proskauer test, citrate utilization, starch hydrolysis, Deamination of Phenylalanine Acid Production from D-Glucose, Gas Production from D-Glucose, Nitrate reduction and Triple sugar iron test. Furthermore, quantitative and qualitative tests were carried out by using $\mathrm{Na}$ tional Botanical Research Institute's phosphate growth medium (NBRIP) to identify phosphate solubilizing bacteria. By measuring the amount of phosphorous solubilized and appearance of halo zones, the identified bacteria were considered as phosphate solubilizing bacteria (Figure 4).

\subsection{Bacterial Response to Malathion Degradation}

For determining the efficiency of isolated microorganism in degrading malathion pesticide National Botanical Research Institute's phosphate growth medium (NBRIP) broth (modified)-contained glucose, $10 \mathrm{~g}$ : malathion [instead of $\left.\mathrm{Ca}_{3}\left(\mathrm{PO}_{4}\right)_{2}\right] ; \mathrm{MgCl}_{2} \cdot 6 \mathrm{H}_{2} \mathrm{O}, 5 \mathrm{~g} ; \mathrm{MgSO}_{4} \cdot 7 \mathrm{H}_{2} \mathrm{O}, 0.25 \mathrm{~g} ; \mathrm{KCl}, 0.2 \mathrm{~g}$ and $\left(\mathrm{NH}_{4}\right)_{2} \mathrm{SO}_{4}, 0.1$ $\mathrm{g}$ was used. The freshly prepared broths were carried out using autoclavable falcon $(50 \mathrm{ml})$ containing $20 \mathrm{ml}$ of medium and autoclaved at $121^{\circ} \mathrm{C}$ for 15 minutes and incubated at $30^{\circ} \mathrm{C}$ overnight. In the next day, broths were inoculated with isolated phosphate solubilizing bacterial colony $(200 \mu \mathrm{l}$ inoculum with approximately $2-3 \times 10^{9} \mathrm{cfu} \cdot \mathrm{ml}^{-1}$ ) in triplicate. Autoclaved uninoculated medium served as control. The broths were incubated for 2, 4, 6 and 10 days at different temperature $\left(25^{\circ} \mathrm{C}, 30^{\circ} \mathrm{C}, 37^{\circ} \mathrm{C}\right)$. The cultures were harvested by centrifugation at 10,000 rpm for $10 \mathrm{~min}$, using centrifugal machine (Hettich Zentrifugen, Germany). Then the samples were filtered for phosphate determination (Figure 5). Inorganic phosphate in the culture supernatant was estimated following the vanadomolybdophosphoric yellow color method using a spectrophotometer as described by Jackson (Jackson, 1958). The amount of inorganic phosphate solubilized in the supernatant was measured from the difference of sample and control media. The increase in inorganic phosphate in the supernatant was taken as the efficiency of microorganism in degrading malathion pesticide. 

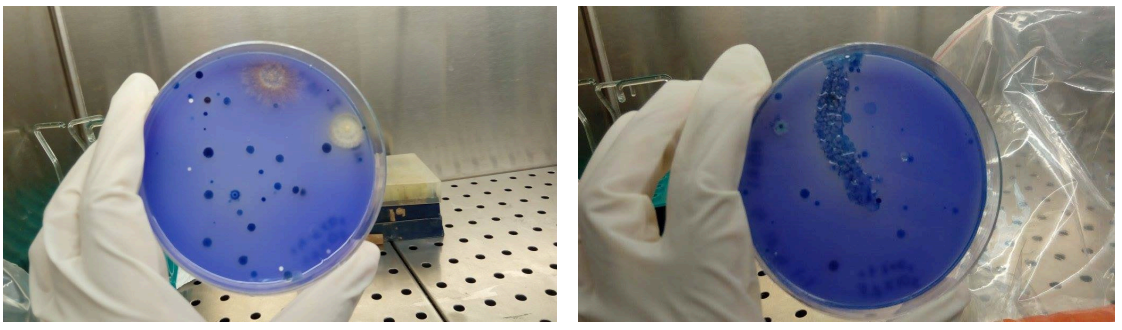

Figure 4. Presence of phosphate solubilizing bacteria in NBRIP solid media.

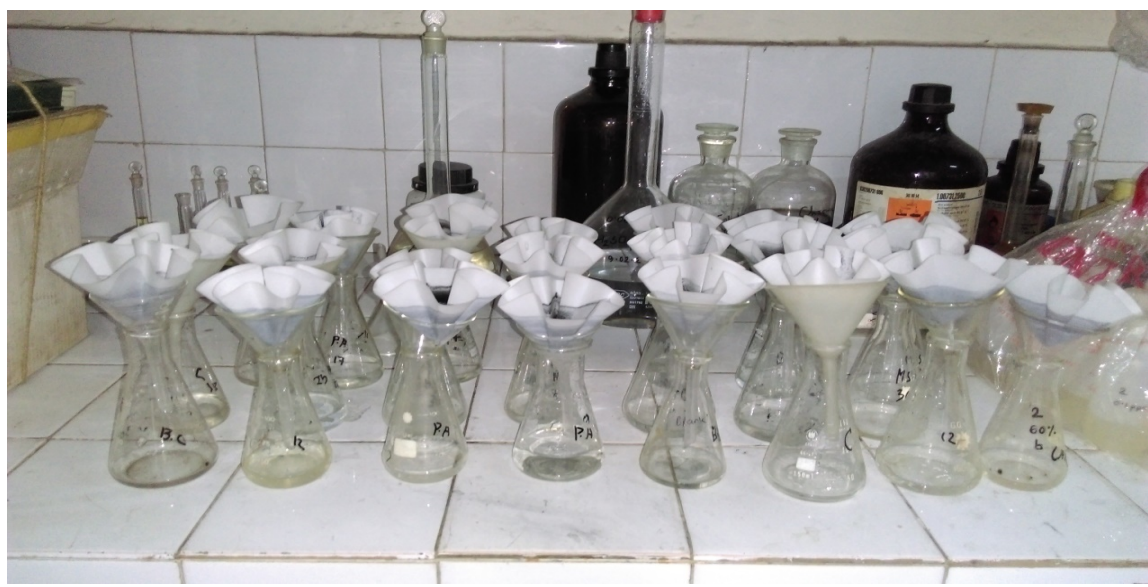

Figure 5. Malathion rich broth culture filtration for determination of soluble phosphate.

\section{Results and Discussion}

\subsection{Isolation and Identification of Phosphate Solubilizing Bacteria}

All soil conditions may not be suitable for growing all types of microorganisms. Vikram et al. (2007) reported a strong positive correlation between organic carbon content, available N and PSB population. Also, Ndung'u-Magiroi et al. (2012) showed a positive and highly significant correlation between PSB and phosphate-solubilizing microorganism (PSM) populations, organic C, exchangeable $\mathrm{Ca}$ and exchangeable $\mathrm{Mg}$, while $\mathrm{pH}$ and extractable $\mathrm{P}$ did not correlate with the PSB population. Winogradsky detected saprophytic Bacillus species in soil, stating that the bacteria's spores became active when an excess of easily decomposable organic matter became available or when the moisture content of the soil was high (Winogradsky, 1924). Pseudomonas aeruginosa is found widely in nature, in soil and water and has few nutritional requirements and can adapt to conditions not tolerated by other organisms (Prince, 2012). Therefore, the chemical parameters of soil samples were measured to determine favorable condition for the phosphate solubilizing Bactteria (Table 1). Among the 5 isolates, only 1 heterotrophic isolate was Gram-positive and rest were Gram-negative aerobic bacteria. Two bacteria named as Raoultella ornithinolytica and Pseudomonas pseudoalcaligenes isolated from agricultural soil of Sirajgonj, Pseudomonas pseudoalcaligenes and Bacillus cereus were isolated from moist soils of Tangail and lastly Pseudomonas aeruginosa and Bacillus subtilis were isolated from 
relatively moist agricultural field of Gazipur. Next, phosphate solubilizing bacteria were identified from isolated bacteria. Table 2 shows that out of the 5 isolates 4 showed phosphate solubilizing capacity. These were Raoultella ornithinolytica, Bacillus cereus, Pseudomonas aeruginosa and Bacillus subtilis. Bacillus cereus was the most efficient phosphate solubilizing bacteria (Figure 6).

\subsection{Observation of Bacterial Response to Malathion Degradation}

In the present experiment, malathion was the sole phosphorous source for microbes in the broth. The amount of soluble phosphate released in the medium proved the degradation of malathion. Malathion degradation was observed at $25^{\circ} \mathrm{C}, 30^{\circ} \mathrm{C}$ and $37^{\circ} \mathrm{C}$ which were presented in Tables 3-5. The phosphorous releasing capacity of these microbes varied with timings and incubation temperature.

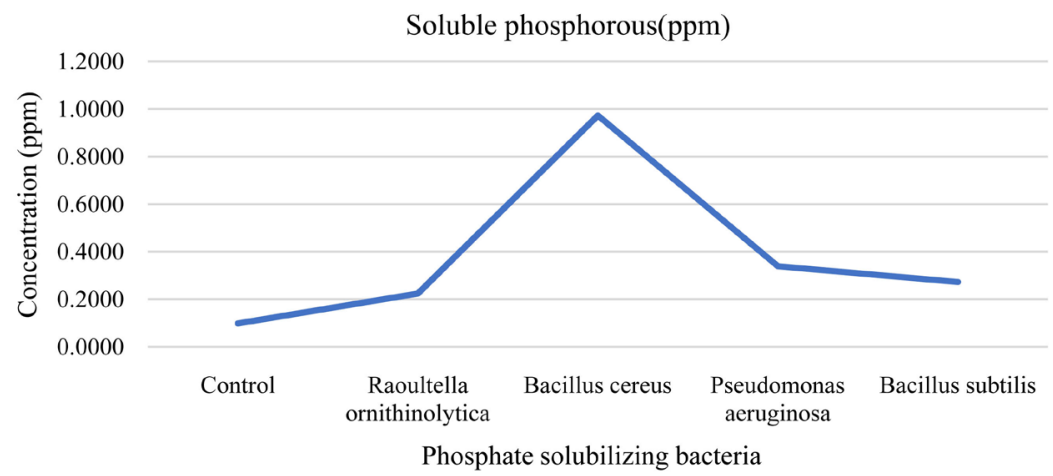

Figure 6. Organic phosphorous solubilizing capacity of Phosphate solubilizing bacteria.

Table 1. Chemical properties of collected soil samples.

\begin{tabular}{cccc}
\hline Parameter & Soil 1 & Soil 2 & Soil 3 \\
\hline Moisture content (\%) & 9.66 & 17.21 & 12.37 \\
pH & 7.85 & 6.90 & 4.25 \\
Total Carbon (\%) & 0.66 & 0.33 & 0.38 \\
Total Nitrogen (\%) & 0.21 & 0.13 & 0.14 \\
Organic matter (\%) & 1.14 & 0.56 & 0.65 \\
C/N ratio & 9.875 & 10.2 & 9.55 \\
Total Phosphorous (\%) & 0.05 & 0.03 & 0.03 \\
Total Potassium (\%) & 0.87 & 0.56 & 0.29 \\
\hline
\end{tabular}

Table 2. Qualitative and quantitative screening of phosphate solubilizing bacteria.

\begin{tabular}{ccc}
\hline Isolates & Presence of halo zone & Soluble phosphorous $(\mathrm{ppm})$ \\
\hline Control & - & 0.0977 \\
Raoultella ornithinolytica & + & 0.2233 \\
Pseudomonas pseudoalcaligenes & - & - \\
Bacillus cereus & - & 0.9721 \\
Pseudomonas aeruginosa & + & 0.3384 \\
Bacillus subtilis & + & 0.2722
\end{tabular}


Table 3. Release of soluble phosphorous by bacterial isolates at $25^{\circ} \mathrm{C}$.

\begin{tabular}{ccccc}
\hline \multirow{2}{*}{ Name of the organism } & \multicolumn{4}{c}{ ppm P released } \\
\cline { 2 - 5 } & $\mathbf{5}$ Period of incubation \\
\cline { 2 - 5 } & $\mathbf{2}$ days & $\mathbf{4}$ days & $\mathbf{6}$ days & 10 days \\
\hline Control & 0.0189 & .0311 & 0.0158 & 0.0005 \\
Pseudomonas aeruginosa & 0.0440 & 0.2011 & 0.0518 & 0.0417 \\
Bacillus cereus & 0.0576 & 0.1735 & 0.0335 & 0.0293 \\
Bacillus subtilis & 0.0665 & 0.1845 & 0.0751 & 0.0466 \\
Raoultella ornithinolytica & 0.0717 & 0.1640 & 0.0480 & 0.0311 \\
\hline
\end{tabular}

Table 4. Release of soluble phosphorous by bacterial isolates at $30^{\circ} \mathrm{C}$.

\begin{tabular}{cllll}
\hline \multirow{2}{*}{ Name of the organism } & \multicolumn{4}{c}{ ppm P released } \\
\cline { 2 - 5 } & \multicolumn{4}{c}{ Period of incubation } \\
\cline { 2 - 5 } & $\mathbf{2}$ days & 4 days & 6 days & 10 days \\
\hline Control & 0.0210 & 0.0023 & 0.0316 & 0.0060 \\
Pseudomonas aeruginosa & 0.0517 & 0.1666 & 0.0651 & 0.0810 \\
Bacillus cereus & 0.0613 & 0.4717 & 0.0786 & 0.0415 \\
Bacillus subtilis & 0.0336 & 0.2018 & 0.0718 & 0.0439 \\
Raoultella ornithinolytica & 0.0861 & 0.1071 & 0.0499 & 0.0339 \\
\hline
\end{tabular}

Table 5. Release of soluble phosphorous by bacterial isolates at $37^{\circ} \mathrm{C}$.

\begin{tabular}{cllll}
\hline \multirow{2}{*}{ Name of the organism } & \multicolumn{4}{c}{ ppm P released } \\
\cline { 2 - 5 } & \multicolumn{4}{c}{ Period of incubation } \\
\cline { 2 - 5 } & $\mathbf{2}$ days & 4 days & 6 days & 10 days \\
\hline Control & 0.0219 & 0.0285 & 0.0207 & 0.0226 \\
Pseudomonas aeruginosa & 0.0732 & 0.0619 & 0.0498 & 0.0514 \\
Bacillus cereus & 0.0552 & 0.0534 & 0.0297 & 0.0480 \\
Bacillus subtilis & 0.0496 & 0.0483 & 0.0590 & 0.0441 \\
Raoultella ornithinolytica & 0.0647 & 0.0504 & 0.0513 & 0.0492 \\
\hline
\end{tabular}

At $25^{\circ} \mathrm{C}$ and $30^{\circ} \mathrm{C}$, the amount of soluble phosphate in the medium increased on the fourth day of incubation and then decreased gradually. This indicated that organisms showed their highest degradation activity on the fourth day of incubation when incubation temperature was fixed at $25^{\circ} \mathrm{C}$ and $30^{\circ} \mathrm{C}$ [Figure 7 (a) and Figure $7(\mathrm{~b})]$. In contrast, at $37^{\circ} \mathrm{C}$ all organisms showed the highest degradation capacity on the second day of incubation except Bacillus Subtilis which degraded most of the pesticide on the sixth day [Figure 7(c)].

Temperature is one of the major environmental factors that influence biodegradation. Furthermore, bacterial metabolism may increase with an increase in temperature (Nadalian, et al., 2016). In the experiment, temperature was found 


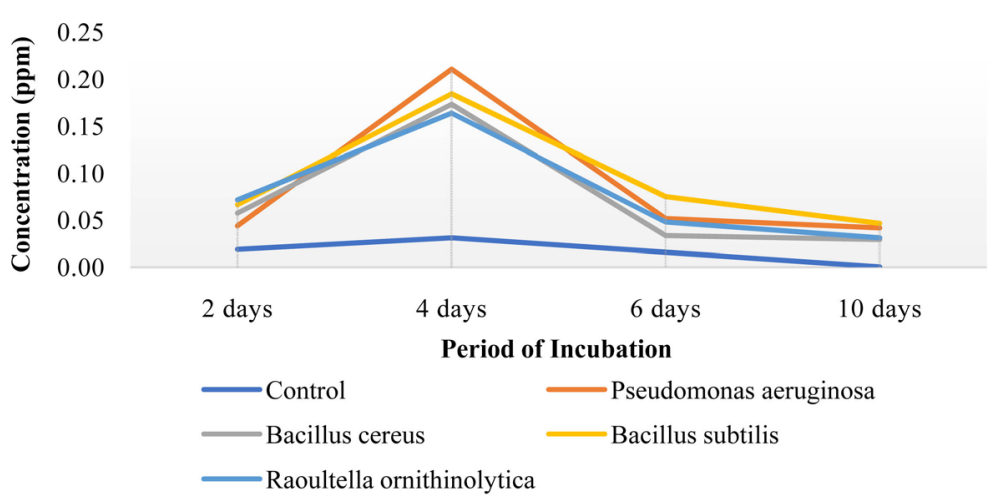

(a)
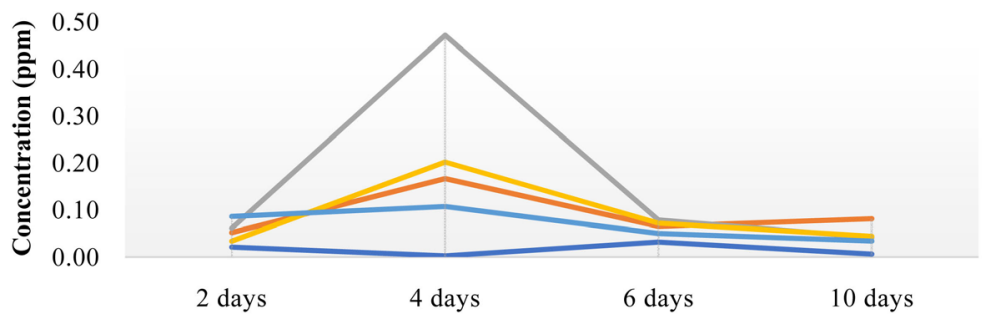

Period of incubation

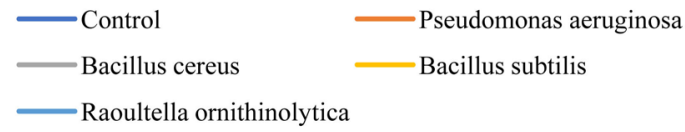

(b)

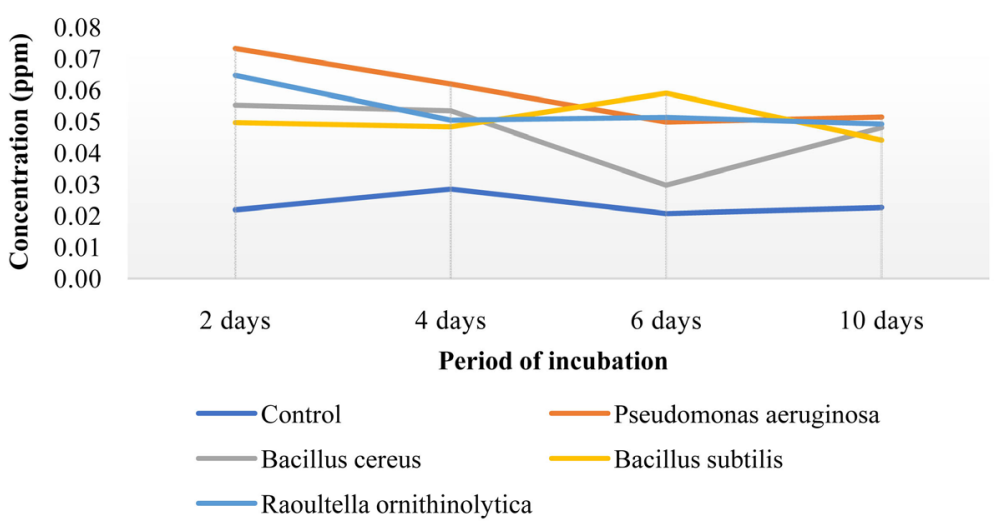

(c)

Figure 7. Amount of phosphate released by phosphate solubilizing bacteria at $25^{\circ} \mathrm{C}$ (a); $30^{\circ} \mathrm{C}(\mathrm{b})$ and $37^{\circ} \mathrm{C}(\mathrm{c})$.

to be a significant factor. It is reported that Bacillus species mainly grow in an optimum temperature of nearly $25^{\circ} \mathrm{C}$ to $30^{\circ} \mathrm{C}$ (Web, 1), Pseudomonas aeruginosa at $25^{\circ} \mathrm{C}$ to $37^{\circ} \mathrm{C}$ (Prince, 2012) and Raoutella ornithinolytica at $37^{\circ} \mathrm{C}$ (Chung, et al., 2016). However, by measuring the amount of soluble phosphorous throughout the incubation period, it was demonstrated that for all organisms, $25^{\circ} \mathrm{C}$ and $30^{\circ} \mathrm{C}$ were the most favorable temperatures for degrading malathion [Figures $8(\mathrm{a})-(\mathrm{d})$ ]. The release of the maximum amount of soluble 


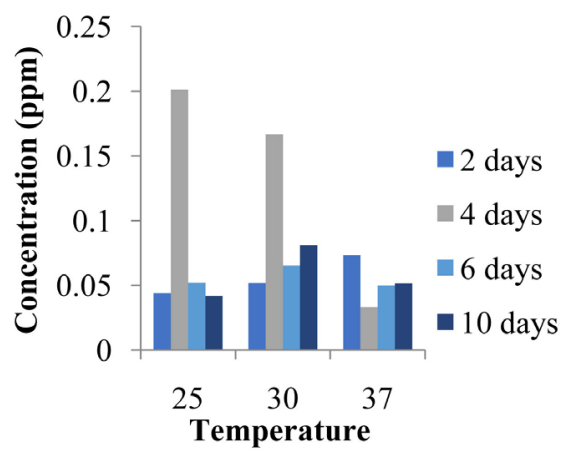

(a)

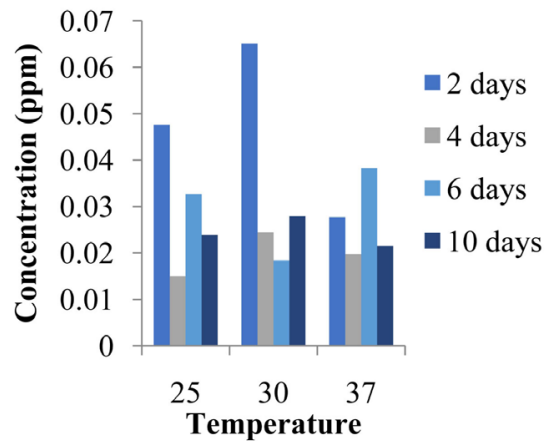

(c)

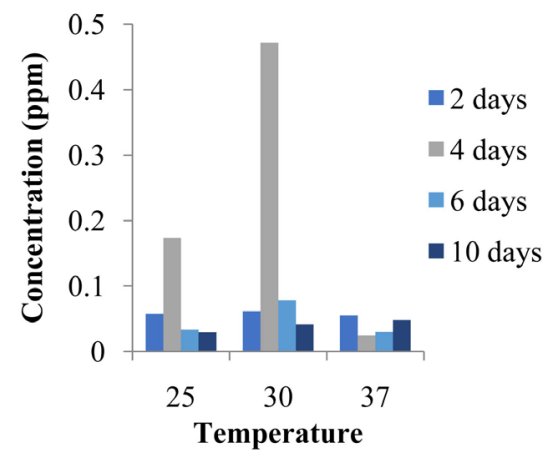

(b)

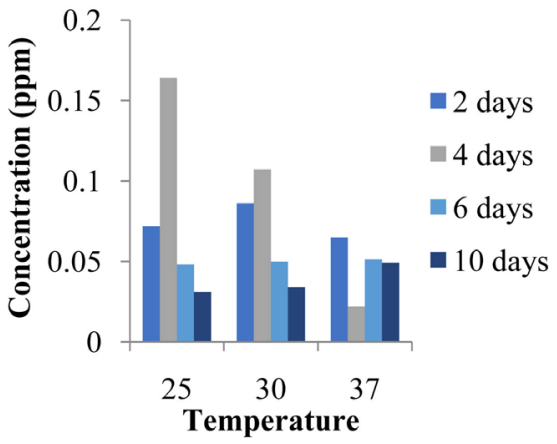

(d)

Figure 8. Effect of temperature on malathion degradation of Pseudomonas aeruginosa (a); Bacillus cereus (b); Bacillus subtilis (c) and Raoultella ornithinolytica (d) at different incubation period.

phosphate at $25^{\circ} \mathrm{C}$ and $30^{\circ} \mathrm{C}$ throughout the incubation period indicated the increase in metabolism activity due to increase in growth of bacterial cells. Moreover, Bacillus cereus followed by Pseudomonas aeruginosa was found to be the most efficient malathion degrading bacteria in this experimentby measuring total amount of phosphorous [Figure 8(a) and Figure 8(b)]. On the other hand, the release of the least amount of phosphorus by Raoultella ornithinolytica indicated that it was the least efficient in malathion degradation [Figure 8(d)].

\section{Conclusion}

It is reported that hydrolysis plays an important role in malathion degradation when $\mathrm{pH}>7$. This is because malathion is responsive to hydrolysis reaction because of its stronger polar nature. Although malathion may be degraded by chemical processes in soil such as chemical hydrolysis, the amount of microbial degradation is far greater than chemical degradation in natural systems (Mulla, et al., 1981). Biodegradation also plays a role when $\mathrm{pH}<7$ and the rate of hydrolysis is slow, relative to the rate of biodegradation (Web, 2). Different types of enzymes have been reported in organic phosphorous compound degradation. These enzymes can either be acid or alkaline phosphomonoesterases (Jorquera, et al., 2011). Under this study efficiency of phosphate solubilizing bacteria in degrading malathion has been investigated. Release of inorganic phosphorous im- 
plies the practical implication of phosphate solubilizing bacteria in mineralizing malathion.

\section{Conflicts of Interest}

The authors declare no conflicts of interest regarding the publication of this paper.

\section{Acknowledgements}

Authors would like to thank the Department of Soil, Water and Environment, University of Dhaka and Food Analysis and Research Laboratory, Centre for Advance Research in Sciences, University of Dhaka for the financial support.

\section{References}

Agnihotri, N. P., Pandey, S. Y., Jain, H. K., \& Srivastava, K. P. (1981). Persistence, Leaching and Movement of Chlorfenvinphos, Chlorpyrifos Disulfoton, Fensulfothion, Monocrotophos and Tetrachlorvinphos in Soil. Indian Journal of agricultural Chemistry, 24, 27-31.

Cappuccino, J. G., \& Natalie, S. (2012). Microbiology, a Laboratory Manual. Pearson Education.

Chung, S. L., Kung, H. F., Lin, C. M., Tsai, H. C., \& Tsai, Y. H. (2016). Histamine Production by Raoultellaornithinolytica in Mahi-Mahi Meat at Various Storage Temperatures. Journal of Food and Drug Analysis, 24, 305-310. https://doi.org/10.1016/j.jfda.2014.06.010

Ghorab, M. A., \& Khalil, M. S. (2016). The Effect of Pesticides Pollution on Our Life and Environment. Journal of Pollution Effects and Control, 4, 159.

Greenberg, E. L., Clerceri, S., \& Eaton, A. D. (1980). Standard Methods for the Examination of Water and Waste Water $\left(18^{\text {th }}\right.$ ed.). Washington DC: American Public Health Association.

Jackson, M. L. (1958). Soil Chemical Analysis. Englewood Cliffs; N.J., USA: Prentice-Hall, Inc.

Jorquera, M. A., Crowley, D. E., Marschner, P., Greiner, R., Fernandez, M. T., Romero, D., et al. (2011). Identification of $\beta$-Propeller Phytase-Encoding Genes in Culturable Paenibacillus and Bacillus sp. from the Rhizosphere of Pasture Plants on Volcanic Soils. FEMS Microbiology Ecololgy, 75, 163-172. https://doi.org/10.1111/j.1574-6941.2010.00995.x

Mulla, M. S., Mian, L. S., \& Kawecki, J. A. (1981). Distribution, Transport, and Fate of the Insecticides Malathion and Parathion in the Environment: Residue Reviews. In F. A. Gunther, \& J. D. Gunther (Eds.), New York: Springer.

Nadalian, B., Moghadam, S. M., \& Ebrahimipour, G. (2016). Biodegradation of Malathion by a Bacterium Isolated from the Arvandkenar Region in Iran. Advances in Environmental Technology, 1, 55-61.

Ndung'u-Magiroi, K. W., Herrmann, L., Okalebo, J. R., Othieno, C. O., Pypers, P., \& Lesueur, D. (2012). Occurrence and Genetic Diversity of Phosphate-Solubilizing Bacteria in Soils of Differing Chemical Characteristics in Kenya. Annals of Microbiology, 62, 897-904. https://doi.org/10.1007/s13213-011-0326-2

Prince, A. S. (2012). In Principles and Practice of Pediatric Infectious Diseases (4th Edition). Amsterdam: Elsevier. 
Ranjard, L., \& Richaume, A. S. (2001). Quantitative and Qualitative Microscale Distribution of Bacteria in Soil. Research in Microbiology, 152, 707-716.

https://doi.org/10.1016/S0923-2508(01)01251-7

Strong, P. J., \& Burgess, J. E. (2008). Treatment Methods for Wine-Related and Distillery Wastewaters: A Review. Bioremediation Journal, 12, 70-87. https://doi.org/10.1080/10889860802060063

Vikram, A., Alagawadi, A. R., Hamzehzarghani, H., \& Krishnaraj, P. U. (2007). Factors Related to the Occurrence of Phosphate Solubilizing Bacteria and Their Isolation in Vertisols. International Journal of Agricultural Research, 2, 571-580.

Web 1: Studies on Factors Affecting Histamine Production during Fermentation and Storage. http://shodhganga.inflibnet.ac.in/bitstream/10603/188862/9/10_chapter\%204.pdf

Web 2: California Environmental Protection Agency (2006). Environmental Fate of Malathion. https://www.cdpr.ca.gov/docs/emon/pubs/fatememo/efate_malathion.pdf

Winogradsky, S. (1924). Microbiologie du sol. Sur l'étude de l'anaerobiose dans la terre. Comptes Rendus de l'Académie des Sciences, 178-186. 